\title{
School organization and the mobilization of teachers and students in the use of a new general secondary education curriculum in East Timor
}

\author{
Ana Capelo ${ }^{1 *}$, Isabel Cabrita ${ }^{2}$ \\ ${ }^{1}$ Research Centre Didactics and Technology in Education of Trainers, University of Aveiro, Portugal \\ \{anacapelo@ua.pt\}@i) \\ ${ }^{2}$ Research Centre Didactics and Technology in Education of Trainers, Department of Education, University \\ of Aveiro, Portugal \{icabrita@ua.pt\}
}

Received on 4 June 2015; revised on 8 June 2015; accepted on 16 June 2015; published on 15 July 2015

DOI: 10.7821/naer.2015.7.135

\begin{abstract}
Given that reforms involving how to deal with the past are extremely difficult, especially when the past involves memories of victimization, death, and destruction so widespread that a high percentage of the population is affected, the main purpose of this article is to describe how the general secondary education (GSE) curriculum in East Timor -an ancient Portuguese colony- is organized in terms of principles and objectives, themes, and methodological guidelines that give priority to assisting students to minimize or manage problems associated with conflict. Subsequently, the current state of GSE is characterized, in terms of school organization and logistics, and mobilization of teachers and students in using the new curriculum. The empirical results show that curricular materials incorporate aspects that can contribute to understanding and minimizing or managing problems created by the conflict, as well as contributing to avoid new conflicts. Nevertheless, although textbooks incorporate these aspects and teachers and students express interest in use them, problems remain regarding their appropriate usage due to numerous factors such as: logistics; school organization and poor teacher skills, despite training given and continued focused investment.
\end{abstract}

KEYWORDS: TIMORESE CURRICULAR REFORM, CURRICULAR MATERIALS, GENERAL SECONDARY SCHOOL, SCHOOL ORGANIZATION, TEACHER AND STUDENT MOBILIZATION

\section{INTRODUCTION}

East Timor (ET) has experienced a transition that has led to rebuilding the country's education system in line with social, economic, political and cultural changes. The last reform initiated in 2010 concerned the restructuring of the general secondary education curriculum (RGSEC). A RGSEC evaluation project recently took place. Based on this restructuring and its evaluation, thispaper attempts to (i) briefly analyse aspects related to the new curriculum which could contribute, or are indeed contributing, to minimizing or

\footnotetext{
*To whom correspondence should be addressed:

Research Centre Didactics and Technology in Education of Trainers,

Dept. of Education, Aveiro University, 3810-193 Aveiro, Portugal.
}

managing problems associated with conflict and to characterize the current state of secondary education in ET, in terms of (ii) school organization and logistics and (iii) mobilization of teachers and students in using the new GSE curriculum. Those aspects will be examined.

\section{CONTEXT AND THE MAIN ASPECTS OF CURRICULUM REFORM OF GENERAL SECONDARY EDUCATION IN EAST TIMOR}

In several countries, numerous groups of citizens go through critical situations and difficulties, such as extreme poverty, hunger and disease. These situations are principally the result of extended periods of occupation by other nations, giving rise to conflicts and unsustainable practices. The destruction of all infrastructures, the loss of skilled people, and the inefficient management of institutions are among the many problems inherited by these countries. Consequently, inhabitants' lives and livelihoods have been disrupted, and basic services such as health and education have been reduced. These factors affect the inhabitants both physically and mentally, hindering social and economic progress (Maiyo, Gladys, Mulwa, \& Mugambi, 2012). ET, a country belonging to the Southeast Asia Pacific region, is in this situation. ET shows the highest youth population rate, probably related to a high fertility rate (Carapic \& Jütersonke, 2012). In addition, serious problems concerning poverty, hunger and social conflicts persist (Carapic \& Jütersonke, 2012). Restructuring education services was considered vital to reversing the situation, and the Strategic Development Plan 2011-2030, consistent with the Millennium Development Goals, highlights the necessity for a better education to build a fair and progressive nation (ME-RDTL, 2011a).

Looking ahead at this central role of education, the ET Government has profoundly restructured the entire education system. With the awareness that one in three Timorese are still in lower secondary education, despite being officially of upper secondary age (UNESCO, 2012), much attention has been paid to improving and expanding the secondary education system, and to also counterbalance the high percentage of basic schoolaged children (ME-RDTL, 2011a). The Ministry of Education of the Democratic Republic of ET (ME-RDTL) (2011a) recognises the necessity to create a new curriculum and new curricular 
materials. Concerning the context of GSE, the ME-RDTL (2011a) requested the cooperation of specific Portuguese institutions, in order to implement the project "Speak Portuguese - Curricular Restructuring of General Secondary Education in East Timor" (2010-2013). The Portuguese language was considered the official language and should thus be used in compulsory general and vocational education. To achieve this, 14 Portuguese teams, maintaining close contact with Timorese political leaders, school directors, teachers and other relevant citizens, were assembled to develop curricular materials, namely a curricular plan, 14 programs, 14 students' textbooks and 14 teacher's guides for each year of schooling $\left(10^{\text {th }}, 11^{\text {th }}\right.$ and $12^{\text {th }}$ years) and for each of the disciplines of GSE. As the basis for the development of the curricular matrix, the teams were guided by a set of principles and purposes expressed in documents of international (e.g. Nolan, 2012) and national scope (Law of Foundations of Education; Program of the IV Constitutional Government 2007-2012) and also documental and empirical data collected at the local level, including data on history, cultural heritage, geography and geology. In order to support this reform, and given the importance of teachers in this process (Moore, 2012), continuous training courses were simultaneously organized by Portuguese teachers to strengthen Portuguese as the language of instruction and to ensure a more substantive implementation of the respective disciplinary programs, as highlighted by numerous studies (Lessing \&Witt, 2007).

After two years of implementation, to identify any shortcomings and to find out what impact all the work had had up to that point, the Timor Project - "Evaluation of the impact of the restructuring of the secondary education curriculum in East Timor - a study in the framework of international cooperation" (2013-2015) was carried out in close collaboration with some of the entities affected by GSE in ET (e.g. Ministry of Education, National Institute for Teacher Training, GSE schools).

The main purpose of the project was to investigate the way in which the new curriculum was being implemented and, according to the results achieved, to give suggestions and recommendations to the Timorese political decision-makers and creators of the curricular materials, bearing in mind the aim of perfecting the process of restructuring of GSE curriculum implementation. To accomplish these goals, and mindful of the fact that monitoring and evaluation should be prioritized in cases like the reform in question (Rogers, 2012), the research team designed a two-phase study: monitoring (phase I) and short-term impact evaluation (phase II) of the restructuring of the secondary education curriculum in ET. The monitoring phase aimed to 1 ) describing and analysing the way the restructuring of the secondary general curriculum was being implemented and 2) establishing the role of the structures, instruments and strategies used in the implementation process. The evaluation phase aimed at 1) describing and analysing the state of GSE regarding the implementation of the transformation agenda and 2) establishing the direction in which the secondary education system is moving and whether this direction is a desirable one, according to the National Education Strategic Plan 2011-2030 and the Millennium Development Goals (Cabrita, Lucas, Capelo, \& Ferreira, 2015). In this respect, by monitoring what was being done, the team was able to assess whether the new curriculum was being implemented as planned and if adjustments to the implementation design needed to be made to fit realities on the ground. By evaluating the intervention the team aimed at determining its relevance, efficiency, effectiveness, impact, and sustainability (Rogers, 2012). The research framework defined for both phases was mainly based on a qualitative methodology, although the use of quantitative methods (inventories) was at times envisaged (Figure 1). Data was collected in Portugal and in ET in May-June 2014 (phase I) and in October 2014 (phase II) at different levels (macro, meso and micro) (Figure 1). It included approximately 750 participants (Lucas \& Cabrita, 2015).

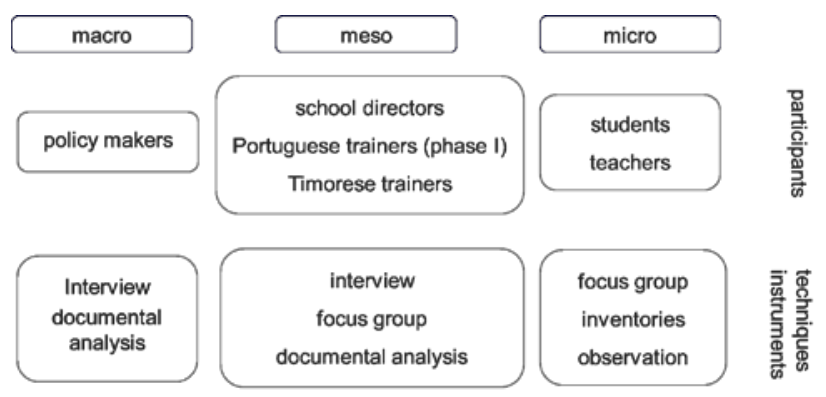

Figure 1. Multilevel mixed methodology (Source: Lucas \& Cabrita, 2015).

\section{RESEARCH METHODS}

The empirical work presented in this article adopts a qualitative and quantitative methodology (Leeuw \& Vaessen, 2009), in accordance with the desired goals (i), (ii) and (iii) referred to in the Introduction.

A a total of approximately 10 intermediate policy makers and school directors, 22 trainers (11 East Timorese and 11 Portuguese) and approximately 200 teachers and 500 East Timorese students participated in the study.

In relation to the first objective, the investigation involved the collection and analysis of documents [Curricular Plan (MERDTL, 2011b)] and Programs of some course units, allowing to characterise the new curriculum in terms of principles, objectives, themes and underlying methodological guidelines which can contribute to helping students minimize or manage problems associated with conflict.

To achieve objective (ii), the investigation was based on data collected in Phase I of Project Timor from the following datacollection instruments: semi-structured interviews with political leaders or intermediate structures of Government, also carried out in Phase II, and with Portuguese trainers; focus group with Timorese trainers, Timorese teachers, also carried out in Phase II; and with Timorese students (Table 1).

Regarding objective (iii), the research was also based on data collected in Phase I of the Project, using the following instruments: semi-structured interviews with political leaders or intermediate structures of Government and with Portuguese trainers; focus group with Timorese trainers, teachers and students; inventories applied to Timorese teachers and students; and field notes made by direct observation of the training sessions. Data collected in Phase II was also included, using the focus group instruments with students.

In order to ensure methodological accuracy, reliability and validity, these research instruments were previously reviewed and validated by the project's consultants and the questionnaires were translated and piloted by native Timorese. 
Table 1. Identification for each objective, data collection instrument, level and participant. Also includes identification by code of the data collection instrument

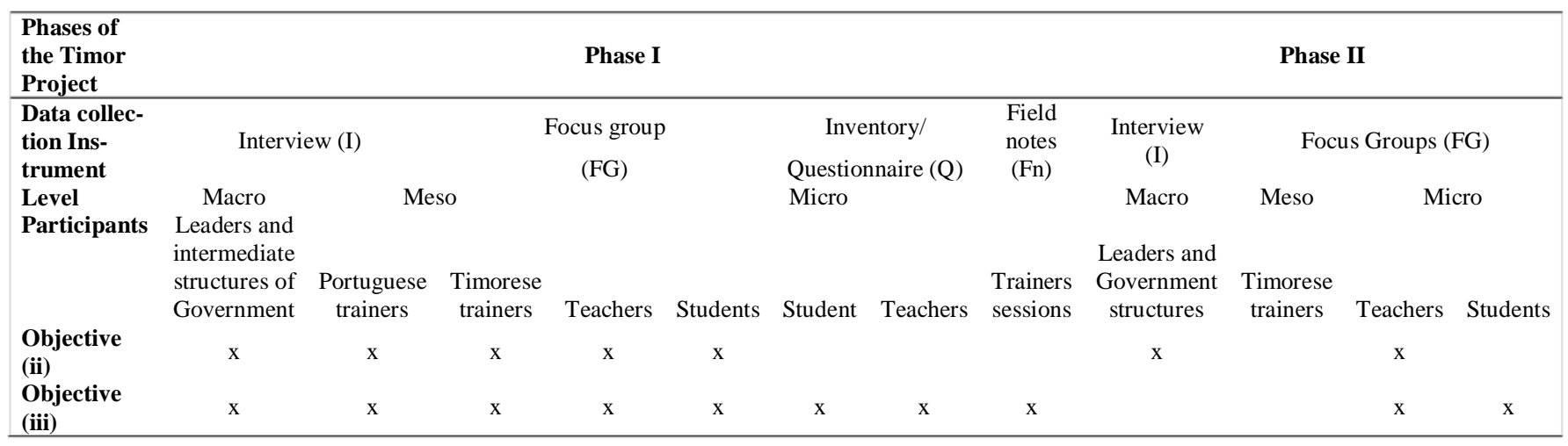

Qualitative data were subsequently subjected to content analysis (Bardin, 2002), based on categories that emerged from the goals referred to above. Quantitative data were submitted to descriptive statistics using the specific software: Statistical Package for the Social Sciences (SPSS).

For a better understanding of the results which follow, the participants were identified with codes (Table 2).

Table 2. Participant identification codes by level and type of session

\begin{tabular}{|c|c|c|c|c|c|}
\hline Level & Designation & Code & Level & Designation & Code \\
\hline \multirow{6}{*}{ Macro } & $\begin{array}{l}\text { Director of an } \\
\text { Educational } \\
\text { Direction } \\
\text { (ED) } \\
\text { Director of } \\
\text { National } \\
\text { Executive of } \\
\text { GSE }\end{array}$ & DNEGSE & \multirow{3}{*}{ Meso } & $\begin{array}{c}\text { Timorese } \\
\text { trainers } \\
\text { (groups 1)* }\end{array}$ & TT1 \\
\hline & $\begin{array}{l}\text { Ex-Director } \\
\text { of an ED }\end{array}$ & exD & & $\begin{array}{l}\text { Timorese } \\
\text { trainers } \\
\text { (groups 2) }\end{array}$ & TT2 \\
\hline & $\begin{array}{l}\text { Advisor to } \\
\text { ex-Director } \\
\text { of an Educa- } \\
\text { tional Direc- } \\
\quad \text { tion }\end{array}$ & AexD & & $\begin{array}{l}\text { Portuguese } \\
\text { trainers }\end{array}$ & PT \\
\hline & \multirow{3}{*}{$\begin{array}{l}\text { Advisor to } \\
\text { Director }\end{array}$} & \multirow{3}{*}{$\mathrm{AD}$} & \multirow{3}{*}{ Micro } & Students & S \\
\hline & & & & Teachers & $\mathrm{T}$ \\
\hline & & & & $\begin{array}{l}\text { Training } \\
\text { sessions }\end{array}$ & TS \\
\hline
\end{tabular}

Note*: there are two groups of trainers, a group that has developed training in 2012 and the other that developed in 2013

The subjects taught by the teachers are also identified by codes (Table 3).

Finally, triangulation was carried out between all data sources to validate the findings (Maxwell, 1996), providing critical insights, revealing the value of reform referred to and shedding light on the conditions that may have affected outcomes.
Table 3. Subject identification codes

\begin{tabular}{|c|c|c|c|c|}
\hline Subjects & Code & Subjects & Code & Subjects \\
\hline Biology & Bio & Geology & Geo & Chemistry \\
\hline $\begin{array}{l}\text { Citizenship and } \\
\text { Social Develop- } \\
\text { ment }\end{array}$ & CSD & History & Hist & Sociology \\
\hline $\begin{array}{l}\text { Economics and } \\
\text { Quantitative } \\
\text { Methods }\end{array}$ & EQM & English & Eng & $\begin{array}{l}\text { Multimedia } \\
\text { Technologies }\end{array}$ \\
\hline Physics & Phys & Mathematics & Math & $\begin{array}{l}\text { Themes of } \\
\text { Literature and } \\
\text { Culture }\end{array}$ \\
\hline Geography & Geo & Portuguese & Pt & \\
\hline
\end{tabular}

\section{RESULTS AND DISCUSSION}

A new curriculum always has an underlying matrix which incorporates a set of principles and objectives, themes, and methodological guidelines, which should be put into practice with a view to improving the quality of teaching, which will be examined.

\subsection{Characterization of the new curriculum for GSE}

For the implementation of the current curriculum for GSE, 14 Portuguese teams, which established close relations with counterpart Timorese teams, were involved (PRCESGTL, 2014). The work of the Portuguese teams was carried out under the restructuring of GSC, resulting in the production of curricular materials (CM). The first of these $\mathrm{CM}$ to be produced was the curricular plan (CP) (ME-RDTL, 2011b) followed by the Programs.

The CP comprised three components, each with respective subjects (Table 4). 
Table 4. Organization of the curricular plan (adopted from ME-RDTL, 2011b)

\begin{tabular}{ccc}
\hline $\begin{array}{c}\text { Science and Techno- } \\
\text { logies Component }\end{array}$ & General Component & $\begin{array}{c}\text { Social Sciences and } \\
\text { Humanities Com- } \\
\text { ponent }\end{array}$ \\
\hline (ST) & \multicolumn{1}{c}{ (GC) } & (SSH) \\
& $\begin{array}{c}4+4 \text { subjects in the } \\
10^{\text {th }} \text { and in the } 11^{\text {th }} \\
\text { years } \\
4 \text { subjects }\end{array}$ & 5 subjects \\
& $12^{\text {th }}$ year & \\
\hline
\end{tabular}

The subjects/disciplines in each component are as follow:

A general component (GC), integrating Physical Education and Sport, Indonesian, Tetum and Religion and Moralsi, Citizenship and Social Development, English, Portuguese, and the new discipline of Multimedia Technologies;

A specific component of Science and Technology (ST), integrating Biology, Physics, Mathematics, Chemistry and the new discipline of Geology and

A specific component of Social Sciences and Humanities (SSH) - integrating Geography, History, Sociology and the new disciplines of Economics and Quantitative Methods, and Themes of Literature and Culture (Cabrita, Capelo, \& Ferreira, 2015)

Common to both specific components, the teams organized a GC, which include disciplines that enable deepening knowledge important for students' education (ME-RDTL, 2011b).

Aware of the importance of teachers as mediators of curricular practices (Shawer, 2010), these teams also created students textbooks and teacher guides for 14 subjects and for each year of schooling $\left(10^{\text {th }}, 11^{\text {th }}\right.$ and $\left.12^{\text {th }}\right)$. A great consistency between all these materials is therefore guaranteed (Cabrita, Capelo, \& Ferreira, 2015).

In accordance with the principles and purposes expressed in documents of international (e.g. Nolan, 2012; UNESCO, 2005) and national scope (Law of Foundations of Education; Program of the IV Constitutional Government), the new curriculum is oriented towards the development of universal values, fundamental to the construction of a national identity (MERDTL, 2011b) and, consequently, consistent with valuing education and the preservation of the culture and history of the country.

The CP that was developed highlights the principles of the Education for Sustainable Development Decade (2005-2014) based on several priorities, among them improving and reorienting the existing system of education towards "respect for cultural diversity and a commitment to create local and globally a culture of tolerance, non-violence and peace” (UNESCO, 2005, p. 43). Furthermore, the CP is in line with other United Nations initiatives, such as Education for All (UNESCO, 2014) and the United Nations Literacy Decade 2013-2012 (Richmond, Robinson \& Sachs-Israel, 2008), in order to stimulate students to improve their literacy and participate responsibly in society.

In this context, it addresses the development "of literacy and specific and transversal skills” (ME-RDTL, 2011b, p. 18), namely, through three curricular areas - (i) linguistic, (ii) scientific, and (iii) personal and social development - which are essential in enhancing individuals and culture, and also in promoting autonomy.

For example, in the area of linguistic development in the context of disciplines of the GC, such as Tetum, Portuguese, English and Indonesian, as well as disciplines of SSH, the Portuguese language is not only seen as a form of communication, but also as a cultural and artistic vehicle (id).

In the area of personal and social development, concerns remain which were already present in the previous cycle (presecondary education) in disciplines such as Civics, Citizenship and Human rights, and skills for Life and Work, now subsumed within Citizenship and Social Development, Sociology and other Programs. Featured as a great novelty in the CP of the GSE is the introduction, in the GC, of the discipline of Multimedia Technologies for all students. This aims to expose students to the reality of current information and communication technology, preparing them for the challenges of global society, progressively and according to the reality and possibilities of the country (id).

In the area of scientific development, CP prioritizes a set of curriculum guidelines to put into practice, for each one of its three components, as exposed therein.

Focusing on the GC, it consists of a set of disciplines, that share the objective of integrating individuals in the information society and stimulating them to actively participate in the construction of this society. The disciplines promote the development of individual, cooperative and collaborative methods of work and study, thus building students' autonomy, critical thinking, problem solving and teamwork (id).

In an integrated manner, as mentioned in the $\mathrm{CP}$, "this training component will contribute to the consolidation of the identity of East Timor based on the appreciation of tradition, plurality of cultures, and innovation and openness to new experiences and relationships" iii (ME-RDTL, 2011b, p. 24). As a whole, as described in the GC, it aims to contribute to:

"The conscious appreciation of tradition and plurality, while deepening identity factors;

The development of attitudes and behaviour of committed and participatory citizenship at the local, national and global level (...);

The adoption of autonomous, cooperative and collaborative work habits, (...) and encouraging of respect for difference and diversity” (id, p. 24).

All these objectives are in line with the promotion of participatory citizenship and towards conflict resolution.

In particular, SSH "emphasize the development of critical capacity and methodical reflection” (id, p. 28), to understand and better manage situations of human conflicts.

In ST, "practical and experimental activities aimed at problem solving are valued" (id, p. 26), and "are developed in the context of the East-Timorese reality, in order to facilitate the recognition by students of the potential of knowledge building” (id, p. 25). The involvement of students is also vital to better understand current problems, both locally and globally (id).

Both of the two components (SSH and ST) include new disciplines, such as Citizenship and Social Development, Geology, History and Themes of Literature and Culture, which are clearly consistent with the guidelines of the CP. For example, Citizenship and the Social Development Program aims to contribute to: 
"Deepening political literacy as a fundamental mechanism for effective participation in political life and in decisionmaking processes;

Consolidating personal and social identity, promoting an awareness of self and the other (...);

Contributing to the consolidation of a democratic and national identity for the strengthening of social cohesion through the appreciation of the sense of belonging and respect for ethnic and cultural diversity and gender equality” (id, p. 35).

The discipline of Geology, to give another example, puts emphasis on the development of the citizen.

The discipline of History is also concerned with purposes such as developing, in the study of historical societies, an aesthetic sensibility and a system of democratic values open to cultural diversity. Moreover, disciplines such as Themes of Literature and Culture incorporate aspects that can contribute to the understanding and minimizing or managing problems created by conflict, as well as contributing to avoiding new conflicts.

In GC, the themes are related with the sociolinguistic reality of ET including with the linguistic values expressed through multiple languages and dialects. Among the set of included disciplines, Citizenship and Social Development, for example, covers topics related to the assumption of duties and the recognition of the importance of State power and, on the other hand, personal development and individual and collective rights; and Multimedia Technologies explores contents related to digital tools and communication utility, search, selection and information management, as well as shared construction of knowledge.

In terms of content, the ST component favors "an approach with a greater degree of depth and complexity" (id, p. 25) of subjects, such as Chemistry, Biology, Physics referred to in the MDGs and in documents relating to Education for Sustainable Development (UNESCO, 2005, 2012), "to consolidate and extend the students' skills and stimulate the construction of disciplinary and interdisciplinary knowledge" (ME-RDTL, 2011b, p. 25). The themes in Geology covered also address the well-being of human beings, economic development, social progress and how this interacts with the environment (MERDTL, 2011b).

In $\mathrm{SSH}$, the new content is interdisciplinary and relates to current issues such as "the valuing of natural resources, the fight against poverty and social exclusion, and the promotion of human rights” (id, p. 27). There are also common concerns regarding students' involvement in and relationship with the world, and their understanding of global phenomena (id), such as current problems, many resulting from situations of conflict (Cabrita, Capelo \& Ferreira, 2015). Moreover, disciplines such as Themes of Literature and Culture, Geography and Sociology incorporate subject matters directly related to specific features of the culture, geography and society of ET.

Concerning the methodological guidelines, the three components (GC, ST and SSH) follow a constructivist perspective of learning (Valadares, 2011) and an exploratory type of teaching (Moore, 2012) that, in turn, enhance the competences development, understood as the ability to build and/or mobilize knowledge, skills and attitudes and values.

In general terms, the $\mathrm{CM}$ are based on student-centered education and a model of action-oriented learning (ME-RDTL, 2011b).
All components value diverse forms of work with a view to collaboration between students and between students and teachers, useful for the development of open relations, mutual respect and mutual help between all (id). In this way, students recognise the importance of cooperating together and considering ways of resolving problems by enhancing the exercise of citizenship.

In sum, despite the positive points of the new curriculum, appropriate to the challenges that ET currently faces, its implementation constitutes a huge challenge, as described below.

\subsection{Organization and logistic}

Certain aspects of the conditions in which the new curriculum is being implemented seem to be peculiar to the Timorese context, such as administrative organization and logistics as exposed in the following sections.

\section{Organization}

The data showed that very few schools had an administrative body and non-teaching staff apart from the director and deputy director, or an organization of teaching staff by discipline area or group (I-D-30.5.14; I-exD-14.5.14).

Moreover, several directors did not have the appropriate profile or training for the position, which may compromise the quality of management at schools (I-exD-14.5.14). This can influence the process of hiring teachers, as in many cases the choice depends exclusively on the school director's decision and not on criteria which take into account the teachers' area of expertise. In many cases, therefore teaching staff is not a judiciously distributed of teaching staff, which is particularly worrying with regard to the new disciplines in the new curriculum, namely Geology, Geography, Economics and Quantitative Methods, Themes of Literature and Culture, and Multimedia Technologies (FG-T-ES4SET-21.5.14).

This often resulted in an uneven distribution of the weekly timetable load in the mostly public schools involved in the study (I-AD-14.5.14), which is not in keeping with the guidelines of the new CP. The situation varies from school to school, depending on the number of classrooms available, and classes in each of the components and years (FG-T-21.5.14).

Another negative aspect relates to the excessive number of students per class (e.g. I-exME-13.5.14; FG-T-10.6.14). Schools are simply incapable of meeting demands in terms of the number of students in secondary education. Many recognize that it is essential to create new conditions including the construction of new buildings and the repair of those that are damaged, as well as the supply of chairs and tables for every school (I-D-30.9.14).

\section{Logistic}

The lack of schools and road infrastructures is highlighted by all educational policy-makers and was observed locally by a team researcher. Apart from the lack of basic amenities such as water (I-PT-Chem-28.1.14), electricity (I-PT-Geol-27.1.14), and sanitation, most of the schools involved in the study do not have adequate installations -classrooms (FG-T-ES4SET-21.5.14) and furniture (I-PT-Phys-28.1.14)- for all the students who attend. Consequently, there are too many students per classroom, making it extremely difficult to entirelycomply with the new curriculum (FG-T-ES12NOV-12.6.14)

Other constraints be connected with the lack of laboratories and lab equipment to conduct practical lessons and experiments 
in the disciplines of Biology, Chemistry and Physics; a lack of multimedia equipment (e.g. I-D-30.5.14; FG-S-ESSMC13.10.15) and a lack of other resources such as dictionaries, bibliographies for specific disciplines and maps (e.g. FG-SESNKS-21.10.15).

This situation is aggravated by the lack of teachers for certain subject areas, for example Geography (FG-S-ESNKS-21.10.15). Others constraints are related to a limited access or lack of programs (e.g. I-PT-Chem-28.1.14), teacher guides (e.g. FGTT1-7.6.14) and students textbooks (e.g. I-PT-Math-24.1.14).

As a way to overcome this limitation, some school directors purpose the print of digital format of the textbooks and, after that, making photocopies (I-AexD-14.5.14).

\subsection{Mobilization of the curriculum}

\subsubsection{By teachers}

Although use of curricular materials in schools was affected by student textbooks not being printed on time, distribution delays (mainly in relation to the $11^{\text {th }}$ year) and by an inadequate number of books being distributed- facts recognised by various leaders interviewed- (e.g. I-D-30.5.14), results obtained from the questionnaire show that a significant percentage of teachers always used the curricular materials (Table 5).

Table 5. Frequency of use of new curricular materials by teachers (\%)

\begin{tabular}{ccccc}
\hline & $\begin{array}{c}\text { Students' } \\
\text { textbook }\end{array}$ & $\begin{array}{c}\text { Teacher's } \\
\text { guide }\end{array}$ & $\begin{array}{c}\text { Curricular } \\
\text { plan }\end{array}$ & $\begin{array}{c}\text { Curricular } \\
\text { program }\end{array}$ \\
\hline $\begin{array}{c}\text { Never } \\
\text { Sometimes }\end{array}$ & 4.1 & 6.6 & 2.5 & 0.8 \\
Often & 0.8 & 7.4 & 13.2 & 12.4 \\
$\begin{array}{c}\text { Always } \\
\text { No/invalid } \\
\text { answer }\end{array}$ & 11.6 & 16.5 & 15.7 & 11.6 \\
\hline
\end{tabular}

In ascending order, the curricular materials which are most used (often or always) are the CP (81\%), teacher guides (82.6\%), subject programs (84.3\%) and, markedly ahead, the students textbooks (92.4\%). The greater use of the programs over the teacher's guide could be explained by the fact that the former orient planning and determine the contents to be assessed in the national exams (FG-T-CPVI- 2.6.14).

However, it is noteworthy that $6.6 \%$ of teachers admitted to never using the teacher's guide, and $4.1 \%$, the students' textbook. One of the reasons for this, expressed by some of the teachers, is the fact that there were not enough resources for all teachers (FG-T-ESPL-3.6.14, FG-T-ES28NOV-11.6.14). This situation leads to teachers using textbooks only when they are not in use by other teachers, or making photocopies of certain parts (Cabrita et al., 2015).

In terms of functionality, textbooks are often or regularly used, given that they constitute the basis for the preparation and implementation of all lessons. Textbooks are mainly used for simple exposure to contents (generally in the order given in the textbook), which are explained via photocopies, through dictation, or through reading to theclass; for doing exercises; and for exploration of the glossaries.

Textbooks also tend to be used in some cases to link the three years within the framework of the same discipline $-10^{\text {th }}, 11^{\text {th }}$ and $12^{\text {th }}$ years (e.g. FG-S-ES4SET-15.10.14) or connect related discipline programs (FG-S-ESSMC-13.10.14). Teacher's guides are used more to aid in the planning of lessons, when lessons are planned, and for the teacher to consult, given that the guides orient the work in the students' textbooks. More specifically, teachers use the guides, among other things, to expand their knowledge of science, follow the proposed teaching steps, and look up answers to exercises (e.g. FG-T-SM-10.6.1).

The subject programs are mainly used in the context of training, and even then, only sporadically, essentially for medium and long-term planning. Use of the CP is more limited and is generally restricted to the initial training sessions, especially to understand the overall logic of the curricular restructuring.

Although the data referred to above lead one to predict that the CM will indeed be widely used by the Timorese teachers, their use (or non-use) is often determined by gaps in the teachers' curricular, scientific, linguistic and didactic knowledge, making it difficult for them to face the challenges of the restructuring of the GSE curriculum in the immediate future. The situation is even more serious concerning the subjects which were introduced into ET for the first time, such as Economics and Quantitative Methods, Geography, Geology, Multimedia Technologies, and Themes of Literature and Culture. For instance, at the curricular level, many participants of the study identified difficulties that the Timorese teachers had in understanding the $\mathrm{CP}$ and parts of the programs. Also highlighted were difficulties in:

a) understanding the logic of skills and identifying the specific guidelines (I-PT-Math-24.1.14);

b) establishing connections between the content of basic education and GSE (FG-T-ES4SET-21.5.14), and between theory and day-to-day practicalities (FG-TESPL-3.6.14);

c) managing all the content and implementing the methodological guidelines advocated (Fn-TS-Soc27.5.14).

In educational terms, according to the respondents, teachers are not used to practicing the type of teaching and learning which is advocated (I-PT-Phys-28.1.14). In fact, teaching still relies on knowledge transfer (I-PT-Math-24.1.14), and the methodology is clearly traditional -firstly reading a text, sometimes reading in chorus, followed by a written questionnaire and finally grammar. This model can, however, work in favour of the new curriculum, since teachers were trained to be curriculum transmitters (Shawer, 2010); therefore if they simply transmit information, they at least transmit the clear purposes of an education for peace and conflict management (Cabrita et al., 2015). In the same vein, many respondents identified the difficulties of Timorese teachers in giving formative and regulatory assessments, and in applying various kinds of evaluation tools (I-PT-Phys-28.1.14; FG-TT2-7.6.14).

\subsubsection{By students}

Use of curricular materials by students was almost entirely limited to students' textbooks and, at the start of the implementation of curricular restructuring, conditioned by the delayed distribution of the books (I-PT-Pt-23 \& 24.1.14). Of the students in possession of textbooks, $56.7 \%$ of those interviewed affirmed that they always or often used them (Table 6).

It should also be noted that a small percentage, 5.8\% (Table 6) never use the textbook. This can be at least partially explained by the fact that there were delays in the preparation of these resources, and consequently in their availability in the schools (Cabrita et al., 2015). 
Table 6. Frequency of use of resources by students during implementation of the current general secondary education curriculum (\%)

\begin{tabular}{|c|c|c|c|c|c|c|c|c|}
\hline & $\begin{array}{l}\text { Students' } \\
\text { textbook }\end{array}$ & $\begin{array}{l}\text { Paper and } \\
\text { Pencil/pen }\end{array}$ & $\begin{array}{c}\text { Blackboard } \\
\text { and } \\
\text { chalk }\end{array}$ & $\begin{array}{l}\text { Card, newspapers } \\
\text { and magazines }\end{array}$ & Computers & Internet & $\begin{array}{l}\text { Other } \\
\text { books }\end{array}$ & $\begin{array}{c}\text { Other technologica } \\
\text { resources }\end{array}$ \\
\hline Never & 5.8 & 6.6 & 3.1 & 47.2 & 64.8 & 65.1 & 18.9 & 68.5 \\
\hline Sometimes & 30.7 & 11.3 & 5.5 & 30.2 & 13.9 & 17.3 & 39.1 & 11.5 \\
\hline Often & 13.9 & 5.5 & 5.2 & 7.3 & 6.6 & 4.5 & 15.7 & 6.8 \\
\hline Always & 42.8 & 70.9 & 77.4 & 7.6 & 8.1 & 6.6 & 18.4 & 5.8 \\
\hline $\begin{array}{c}\text { No/invalid } \\
\text { answer }\end{array}$ & 6.8 & 5.8 & 8.7 & 7.6 & 6.6 & 6.6 & 7.9 & 7.3 \\
\hline
\end{tabular}

Apart from the blackboard and chalk, paper and pencil or pen, it seems that student textbooks generally score the highest in the categories always and often. Also noteworthy is the fact that $65.1 \%$ of students indicated that they never used the internet, $64.8 \%$ never used computers and 68.5\% never used other technological resources (table 6), since most didactic materials such as those do not exist. Other books (39.1\%), and card, newspapers and magazines (30.2\%) were only sometimes used (Cabrita et al., 2015). They probably don't have access to these resources.

Most students who answered the questionnaire indicated that they essentially used the textbook at school, either in the classroom or library (88.4\%), while only a few used this resource at home: $9.5 \%$ using it at home and school, and $1 \%$ exclusively at home (all students in the latter two categories came from ST) (id).

Continuing with use made of the textbook, $88.7 \%$ of students revealed that they employed it to accompany the topics that the teacher is reading or explaining; $85.8 \%$, to study; $84.8 \%$, to clarify doubts; $83.5 \%$, to summarize work done in lessons; and $82.4 \%$, to do revision exercises of topics given. Other uses mentioned were to find out information (78\%), carry out group work (77.2\%), and execute activities solicited by the teacher (71.7\%).

Data collected from the FG differ from the opinions given in the questionnaires, in that some students in the former mentioned that they did not have textbooks for some subjects (e.g. FG-S-ES4SET-21.5.14), and in some school years (e.g. FG-S-ES12NOV-12.6.14). Students consider that the textbook are well organised and structured, with sufficient and appropriate images, and adapted to the reality of the country (e.g. FG-S-ESSMC-6.6.14).

Students also believe that the complexity of the language used in the new materials obliges teachers to complement lessons with more accessible materials from the old curriculum, such as Indonesian and Brazilian textbooks, or resort to dictionaries to look up certain terms or clarify any doubts (e.g. FG-S-ES4SET21.5.14; FG-S-ES12NOV-12.6.14). Due to these difficulties, many students recognize that, when studying alone, they end up consulting the internet through mobile phones (FG-S-ESNKS5.6.14; FG-S-ES12NOV-2.10.14) or tablets (FG-S-ES12NOV2.10.14).

\section{CONCLUSIONS}

The new GSE curriculum includes principles, objectives, methodological guidelines and themes which incorporate aspects that can contribute to understanding and minimizing or managing problems created by conflict, as well as contribute to avoiding new conflicts.

However, it is not known how teachers and students, truly incorporate or integrate the principles, objectives and values of the new curriculum, including the intentions explained above.

It seems that the long period of Indonesian occupation during which it was forbidden to use the Portuguese language, during which infrastructure and school buildings were destroyed, and the tradition of an expository, transmissive method of teaching was continued, along with a lack of teachers qualified to teach in terms of scientific and pedagogical training (Almeida, Martinho \& Cabrita, 2014) all influence and in some way condition the way in which the new curriculum is being implemented (Cabrita, Capelo, \& Ferreira, 2015).

Despite these limitations, it was noted that the new curricular materials are used to different degrees, albeit in a very rigid way, and complemented with guidelines and materials which come from the old curriculum. In such situations, there is often recourse to, among other resources, Brazilian and Indonesian textbooks, as well as to other languages such as Tétum.

Investment in training is seen by all the participants as robust support for the consolidation of the new curriculum (id). Only then can there be competent curriculum makers and developers (Shawer, 2010), able to promote the personal and social development of adolescents to allow them to be (or become more) proactive and reflective citizens (Cabrita et al, 2015), by considering ways of resolving many problems, via enhancing the exercise of citizenship. Finally, the results obtained in this work as well as with others obtained by the Timor Project team will be the starting point for the drafting of the next medium term evaluation project of the RGSEC.

\section{REFERENCES}

Almeida, P., Martinho, M., \& Cabrita, I. (2014). Evaluating the impact of restructuring Secondary Education in East Timor. Procedia-Social and Behavioral Sciences, 141, 665-669. doi:10.1016/j.sbspro.2014.05.116

Bardin, L. (2002). Análise de conteúdo. Lisboa: Edições 70.

Cabrita, I., Lucas, M., Capelo, A., Ferreira, A., Santos, C., Morgado, M., Martinho, M., Albergaria-Almeida, P., Sá, P., Breda, Z., \& Torres, A. C. (2015). Implementar a reestruturação curricular do ensino secundário geral em TimorLeste: construindo qualidade. Aveiro: UA Editora.

Cabrita, I., Capelo, A., \& Ferreira, A. (2015). Ressonâncias da formação de professores face aos desafios do currículo do Ensino Secundário Geral de TimorLeste. In L. R. Oliveira, M. A, Flores, M. A. Moreira, E. Fernandes, P. Santos, D. Pereira, D. Mesquita, S. Fernandes, \& C. Pinheiro (Eds.) Desafios Curriculares e Pedagógicos na Formação de Professores. Ramada: Edições Pedago.

Cabrita, I., Lucas, M., Capelo, A., \& Ferreira A. (2015). Maths in-service teacher training and the restructuring of secondary education in East-Timor. ProcediaSocial and Behavioral Sciences, 186, 649-655. doi:10.1016/j.sbspro.2015.04.129

Capelo, A., \& Cabrita, I. (2015). In-service Teacher Training In The Use Of New Curricular Materials - the particular case of East Timor. The Journal of the 
Seventh World Universities, 8(1), 23-37. Retrieved from http://wuj.cgpublisher.com/product/pub.173/prod.405

Capelo, A., Pedrosa, M. A., \& Albergaria Almeida, P. (2013). What lessons to take from educational reforms in Asia-Pacific region? Factors that may influence the restructuring of secondary education in East Timor. In N. Popov, C. Wolhuter, P. Albergaria Almeida, G. Hilton, J. Ogunleye, O. Chigisheva (Eds.), BCES Conference Books-Education in One World: Perspectives from Different Nations (pp. 91-98). Bulgaria: BCES. (Bulgarian Comparative Education Society). doi:10.4018/978-1-4666-3986-7.ch019

Carapic, J., \& Jütersonke, O. (2012). Understanding the tipping point of urban conflict: the case of Dili, Timor-Leste. Working Paper Series. Understanding the tipping point of urban conflict: violence, cities and poverty reduction in the developing world. Working Paper \#4. Manchester: The University of Manchester. Retrieved from

http://www.urbantippingpoint.org/documents/Working\%20Papers/WP4_Dili.p $\mathrm{df}$

Maiyo, K. J., Gladys, N., Mulwa, D., \& Mugambi, P. (2012). Peace Education for Sustainable Peace and Development: A Case of Kenya. Journal of Research in Peace, Gender and Development, 2(2), 28-33.

Moore, A. (2012). Teaching and learning: Pedagogy, curriculum and culture. Oxon, New York: Routledge.

Lessing, A. \& Witt, M. (2007). The value of continuous professional development: teacher perceptions. South African Journal of Education, EASA 27(1), 53-67. Retrieved from http://www.ajol.info/index.php/saje/article/view/25098

Lucas, M., \& Cabrita, I. (2015). What lies ahead. In Research Day 2015. Aveiro: Universidade de Aveiro.

ME-RDTL (Ministério de Educação, República Democrática Timor-Leste) (2011a). Plano Estratégico de Desenvolvimento 2011-2030. Díli: Ministério da Educação da República Democrática de Timor-Leste.

ME-RDTL (2011b). Plano Curricular do Ensino Secundário Geral. Díli: Ministério da Educação da República Democrática de Timor-Leste

Nolan, C. (2012). 2012 Report on the UN Decade of Education for Sustainable Development, Shaping the Education of Tomorrow, Abridged. Paris: UNESCO. Retrieved from http://unesdoc.unesco.org/images/0021/002166/216606e.pdf

PRCESGTL, Projeto de Reestruturação Curricular do Ensino Secundário Geral em Timor-Leste (2014). Retrieved from http://www.ua.pt/esgtimor/ .

Richmond, M., Robinson, C., \& Sachs-Israel, M. (2008). The global literacy challenge. A profile of youth and adult literacy at the mid-point of the United Nations Literacy Decade 2003-2012. Paris: UNESCO. Retrieved from http://unesdoc.unesco.org/images/0016/001631/163170e.pdf

Rogers, P. J. (2012). Introduction to impact evaluation. In Impact Evaluation Notes, 3. Washington DC: InterAction. Retrieved from http://preval.org/files/Introduction\%20to\%20Impact\%20Evaluation_0\%20Rog ers.pdf

Shawer, S. F. (2010). Classroom-level curriculum development: EFL teachers as curriculum-developers, curriculum-makers and curriculum-transmitters. Teaching and Teacher Education, 26(2), 173-184. doi:10.1016/j.tate.2009.03.015

UNESCO (United Nations Educational, Scientific and Cultural Organization) (2005). Década das nações unidas para o desenvolvimento sustentável (Documento final plano internacional de implementação 2005). Retrieved from UNESCO website: http://unesdoc.unesco.org/images/0013/001399/139937por.pdf

UNESCO (2012). Youth and skills: Putting education to work (EFA global monitoring report 2012). Retrieved from UNESCO website: http://unesdoc.unesco.org/images/0021/002180/218003e.pdf

UNESCO (2014). EFA Global Monitoring Report 2013-2014. UNESCO-UNGEI United Nations Girls' Education initiative (ED-2014/GMR/GS/1). Retrieved from UNESCO website: http://unesdoc.unesco.org/images/0022/002266/226662e.pdf

Valadares J. (2011). A teoria da aprendizagem significativa como teoria construtivista. Aprendizagem Significativa em Revista, 1(1), 36-57. Retrieved from http://www.if.ufrgs.br/asr/artigos/Artigo_ID4/v1_n1_a2011.pdf

\section{ACNOWLEDGMENT}

Funded by: Portuguese Science and Technology Foundation, Potugal; European Commission (FEDER)

Funder Identifier: http://dx.doi.org/10.13039/501100001871;

http://dx.doi.org/10.13039/501100000780

Award: PTDC/MHC-CED/5065/2012

Project: Timor Project - Evaluation of the Impact of

Secondary Education Curricular Restructuring in East Timor

\section{NOTES}

${ }^{i}$ According to our proposal, the coding of a FG carried on, for example, with ES4SET school students, is represented by code FG-S-ES4SET. This code also includes the date of completion of the respective data collection, so that the code used is FG-S-ES4SET-15.10.14.

${ }^{i i}$ The curricular materials of these disciplines were developed by Timorese teams, under the responsibility of the Ministry of Education of the Democratic Republic of East Timor.

iii This quote from ME-RDTL (2011b), as well as the following, are English translation of the excerpt in Portuguese. 